\title{
HTLV-I TAX Gene
}

National Cancer Institute

\section{Source}

National Cancer Institute. HTLV-I TAX Gene. NCI Thesaurus. Code C17366.

Tax gene of the HTLV-I virus. 